logos_i_ethos_2014_1_(36), s.97-110

Rafał Zawisza

\title{
Przeciw melancholii, czyli spór Agaty Bielik-Robson z Giorgiem Agambenem a perspektywy witalizmu mesjańskiego ${ }^{1}$
}

Niemiecki mistyk Jakub Böhme, zgodnie z duchem religijności protestanckiej, w melancholiku widział istotę związaną nieuchronnie $\mathrm{z}$ postacią Szatana, którego towarzystwo wiązało się z kłopotliwą ambiwalencją, gdyż $z$ jednej strony oznaczało groźbę upad$\mathrm{ku}, \mathrm{z}$ drugiej jednak stwarzało „niepowtarzalną szansę na zbawienie"2. Zupełnie podobnie ma się rzecz z filozofią Giorgia Agambena rozpiętą pomiędzy skrajnie rozpaczliwą wizją świata zdominowanego przez paradygmat bio-

Rafał Zawisza (ur. 1988) - absolwent Kolegium MISH UW. Doktorant na Wydziale „Artes Liberales” Uniwersytetu Warszawskiego, uczestnik Międzyuczelnianego Programu Interdyscyplinarnych Studiów Doktoranckich AAL. Przygotowuje rozprawę na temat filozoficznej refleksji nad natalnością. Zajmuje się myślą Hanny Arendt i Hansa Blumenberga, filozofią postsekularną oraz historią gnozy. Członek redakcji czasopisma „Praktyka Teoretyczna”. Publikował m.in. w "Praktyce Teoretycznej” i „Kronosie”. polityczny a radykalną nadzieją ulokowaną w mesjanicznym projekcie „wspólnoty, która nadchodzi” i „bytu quodlibetycznego” jako nowej, wolnej od opresji „formy życia”, pozostającej poza władzą wszelkiego prawa utożsamianego z przemocą.

1 Od czasu powstania niniejszego tekstu (jesienią 2011 roku) zdążyła ukazać się polemika wymierzona w krytykę, jaką Agata Bielik-Robson kieruje wobec Giorgia Agambena. Zob. M. Ratajczak, Podmiot między negatywnością i „Aufhebung/désoeuvrement”. Odparcie kryptoteologicznej krytyki Agambena, „Praktyka Teoretyczna”, 2013, nr 2(8), s. 347-363, http://www.praktyka teoretyczna.pl/PT_nr8_2013_ Teologie/16.Ratajczak.pdf (11.02.2014). Pozostawiam jednak własny tekst w dawnej formie, jako że odniesienie się do polemiki Mikołaja Ratajczaka wymagałoby osobnego artykułu, nie zaś korekty niniejszego.

R. Klibansky, E. Panofsky, F. Saxl, Saturn i melancholia. Studia z historii, filozofii, przyrody, medycyny, religii oraz sztuki, tłum. A. Kryczyńska, Kraków 2009, s. 6. 
W tekście tym projekt Agambena służyć będzie jako negatywny punkt odniesienia pozwalający na prezentację punktów węzłowych witalizmu mesjańskiego proponowanego przez Agatę Bielik-Robson. Celem jest pokazanie napięcia właściwego „antropologii dynamicznej”3 , tzn. takiej, która - aspirując do miana refleksji mądrościowej - chce sprostać subtelnej dialektyce siły i słabości, konieczności i możliwości traktowanych jako „momenty” życia ludzkiego. W tej perspektywie narracja Agambena jawi się jako melancholijna, bowiem poprzestaje na celebracji czystej potencjalności, z gnostyckim lękiem odsuwając się od zajęcia jakiegokolwiek stanowiska i tym samym pozostawiając „nagie życie” wydane na łaskę i niełaskę władzy suwerennej oraz dominacji śmierci. Witalizm mesjański nie tylko unika tych słabych punktów, ale potrafi obrócić je na swoją korzyść, stając się z jednej strony podstawą do formułowania nieutopijnego projektu cywilizacyjnego, $\mathrm{z}$ drugiej - i to będzie zajmowało mnie przede wszystkim - przejawem wyrafinowanej sztuki życia.

W rozprawie Mundus melancholicus Wojciech Bałus określa istotę melancholii słowem "nierozstrzygalność” ${ }^{4}$, z kolei Marek Bieńczyk nazywa ją „czystą nieokreślonością”. W W idiomie witalizmu mesjańskiego sformułowalibyśmy to zapewne następująco: prowadząca donikąd ambiwalencja będąca wynikiem niemożności wyjścia poza immanencję, co u Agambena skutkuje „dezaktywacją” nie tyle „maszyny antropologicznej” i cyklów produkcyjno-konsumpcyjnych, ile raczej samej mesjańskiej nadziei.

Idąc za Bieńczykiem, można wskazywać na kolejne cechy myślenia melancholijnego i odnosić je do elementów projektu homo sacer. I tak, bazą dla niego jest matematyczno-geometryczna wizja świata, podszyta lękiem przed powtórzeniem i świadomością jego nieuchronności, a także samo pojęcie „świata” jako służące do ewokowania wizji transhistorycznych o posmaku ponurej logiki dziejów. Kolejną cechą

A. Bielik-Robson, Romantyzm. Niedokończony projekt. Eseje, Kraków 2008, s. 36.

W. Bałus, „Mundus melancholicus”: melancholiczny świat w zwierciadle sztuki, Kraków 1996.

M. Bieńczyk, Melancholia. O tych, co nigdy nie odnajda straty, Warszawa 1998, s. 13. 
dystynktywną melancholików jest predylekcja do struktur kolistych o pustym centrum ${ }^{6}$. Charakteryzująca nagie życie dynamika ,włączającego wyłączenia" albo rozważania dotyczące chwały z pracy Il regno e la gloria spełniają powyższe kwalifikacje. Dalej: „,...] jedyną uchwytną dla melancholii istotą rzeczywistości..." jest nicość, pustka ${ }^{7}$, co przypomina raz po raz przywoływaną przez Agambena „możność nieistnienia”. Kolejny wyróżnik to paniczny lęk przed koniecznością, powodujący przedkładanie nad nią możliwości i jednocześnie unikanie ich aktualizacji z obawy przed utratą. Bieńczyk streszcza to następująco: „Ta tęsknota [...] jest pragnieniem odmiany podszytym lękiem powtórzenia, pragnieniem, które nie chce pragnąć prawdziwie i głęboko, i okazuje się ostatecznie ruchem powtórzonego okrężnie potwierdzenia status quo"9. Czymże innym jest bowiem przynależna wspólnocie, która nadchodzi "niezbawialność" 10 ? Agamben w zaskakujący sposób stwierdza, że strategicznym celem jego projektu nie jest zniesienie dotychczasowych różnic, lecz zmiana ich funkcji. Nic zatem dziwnego, że podobne stwierdzenia traktowane są jako wyraz dezercji z pola walki o sprawiedliwość społeczną i prowokują oskarżenia o „polityczny nihilizm”"

W tekście Rozbita konstelacja ${ }^{12}$, poświęconym filozofii Agambena, Bielik-Robson demaskuje zawartą w niej dwuznaczność, która łączy się z nierozstrzygalnością między inspiracjami płynącymi od Waltera Benjamina i Martina Heideggera. Oskarża włoskiego filozofa o prowadze-

Tamże, s. 55.

Tamże, s. 83.

O możności nieistnienia Agamben pisze szerzej w komentarzu do dzieła Melville’a, przepojonym wyraźnie Benjaminowską melancholią. Zob. G. Agamben, Bartleby, czyli o przypadkowości, tłum. S. Królak, [w:] H. Melville, Kopista Bartleby. Historia z Wall Street, tłum. A. Szostkiewicz, Warszawa 2009.

M. Bieńczyk, Melancholia..., dz. cyt., s. 118.

10 Zob. G. Agamben, Wspólnota, która nadchodzi, tłum. S. Królak, Warszawa 2008, s. $12,111-114$.

11 Zarzut taki sformułował Ernesto Laclau. Zob. E. Laclau, Nagie życie czy społeczne nie wiadomo co?, tłum. K. Szadkowski, [w:] Agamben. Przewodnik Krytyki Politycznej, red. Zespół Krytyki Politycznej, Warszawa 2010, s. 54.

12 A. Bielik-Robson, Rozbita konstelacja. Teologia Agambena między tragedia a mesjanizmem, tłum. M. Kropiwnicki, [w:] Agamben. Przewodnik Krytyki Politycznej, dz. cyt. 
nie dwóch równoległych narracji, które nie łączą się w przekonywającą całość, lecz wzajemnie się neutralizują, powodując, że Agambenowski mesjanizm chybia celu. Główny zarzut spoczywa na braku wyjaśnienia, w jaki sposób bezbronne i zupełnie ujarzmione nagie życie miałoby przeistoczyć się w mesjaniczną resztkę rozsadzającą porządek suwerennego wykluczenia. Okazuje się, że pozorowany projekt emancypacyjny Agambena powiela porażkę krytykowanej przez niego samego dekonstrukcji, która miała nie poradzić sobie z zakończeniem negocjacji z Prawem ${ }^{13}$.

Wypada również nadmienić, że w myśli Bielik-Robson negatywna ocena tezy włoskiego filozofa głoszącej, że paradygmatem nowoczesnej polityczności jest obóz koncentracyjny, idzie w parze z próbą obrony tejże epoki właśnie jako czasu, kiedy - nie bez pewnych niezaprzeczalnych strat - dokonała się niespotykana w dziejach eksplozja witalnego nagiego życia, owocująca wzrostem gospodarczym i postępem naukowo-technicznym ${ }^{14}$. Agamben zaś, podążając za swym duchowym mistrzem Heideggerem, zdaje się nie zauważać tego wymiaru modernitas, która jawi mu się wyłącznie w aurze apokaliptycznej katastrofy ${ }^{15}$.

Warto na moment przyjrzeć się właśnie recepcji myśli Heideggera w filozofii autora Homo sacer, żeby odsłonić motywację stojącą za jego koncepcją podmiotu. Agamben powołuje się na tekst Emmanuela Levinasa z 1934 roku pt. Kilka myśli o filozofi hitleryzmu, w którym autor stara się pojąć naturę nowego reżimu, ale również postawę Heideggera, czyniąc aluzje do jego filozofowania (ale bez wskazania na osobę). Akcent pada na znaczenie pojęcia faktyczności, które funduje radykalnie ontologiczne i jednocześnie immanentystyczne ujęcie Dasein, przekreślające wszelkie tradycyjne podziały na ducha i materię, kulturę i naturę itp. W ten sposób, jak ujmuje rzecz Levinas, „czynnik biologiczny, wraz z całym fatalizmem,

13 Zob. S. M. Wortham, Law of friendship: Agamben and Derrida, „New Formations”, 2007, nr 62, s. 88-90.

14 A. Bielik-Robson, Romantyzm..., dz. cyt., s. 318-321.

15 Co prawda na początku książki Homo sacer Agamben zastrzega, że nie zamierza przeczyć „ciężkiej pracy i zdobyczom demokracji”, jednak w świetle jego dalszych analiz ten afirmatywny gest wydaje się pusty. Zob. G. Agamben, „Homo sacer”. Suwerenna władza i nagie życie, tłum. M. Salwa, Warszawa 2008, s. 21. 
który z sobą niesie, staje się czymś więcej niż obiektem życia duchowego - staje się jego ośrodkiem"16. Uwięzienie bytu ludzkiego w ciele (identyfikowanym bezwzględnie z całą jego przeszłością) jako „zadaniem” było oczywiście propozycją obarczoną niemałym ryzykiem, szczególnie w owych „mrocznych czasach”, jak zwykła mawiać Hanna Arendt.

Trzeba w tym miejscu wyraźnie stwierdzić, że jedną rzeczą jest konieczność poszukiwania nowej formuły podmiotowości po bankructwie modelu kartezjańskiego, inną rezygnacja z jej konstruowania, która motywację moralną chce czerpać $\mathrm{z}$ tak dramatycznych wydarzeń oraz tarapatów intelektualnych, w jakie popadli niektórzy myśliciele, choćby wybitni. Przypadek Agambena jest w kontekście tych dylematów typowy i wyjątkowy zarazem: typowy, gdyż jak większość filozofów ponowoczesnych opowiada się za drastycznie minimalistyczną wersją podmiotowości, a wyjątkowy z uwagi na figurę, jaka ma być jej egzemplifikacją, mianowicie postacią obozowego muzułmana ${ }^{17}$. Pomysł ten wydaje się nie tylko nietrafiony, ale wątpliwy ze względów etycznych, powstaje bowiem pytanie, czy takie „użycie” (mówiąc żargonem Agambena) nie jest nadużyciem i czy nie stawia to pod znakiem zapytania forsowanego przez włoskiego filozofa aktu profanacji jako znalezienia odmiennego zastosowania ${ }^{18}$.

Złożony stosunek Agambena do dziedzictwa Heideggera polega na konceptualnym uporze przy immanencji, ale poprzez silne dążenie do wyklarowania w niej biegunowości, co wielokrotnie, szczególnie w lekturze pierwszego tomu z cyklu Homo sacer, skutkuje dezorientacją co do intencji autora, obarczonego, jak zaznaczyłem na początku, melancholijną

16 E. Levinas, Kilka myśli o filozofii hitleryzmu, tłum. J. Migasiński, „Literatura na Świecie”, 2004, nr 1-2, s. 10-12, cyt. za: G. Agamben, „Homo sacer”..., dz. cyt., s. 207. Zob. więcej: tamże, s. 204-210.

17 Zob. G. Agamben, Co zostaje z Auschwitz: archiwum i świadek, tłum. S. Królak, Warszawa 2008.

18 Krytycznie na temat analiz Agambena związanych z Auschwitz pisali m.in. Ewa Domańska i Adam Lipszyc. Zob. W sprawie Agambena. Konteksty krytyki, red. Ł. Musiał, M. Ratajczak, K. Szadkowski, A. Żychliński, Poznań 2010. Instruktywne może okazać się także posłowie pióra Grzegorza Jankowicza i Pawła Mościckiego do Stanu wyjątkowego, gdzie autorzy wspominają także o krytyce zagranicznej. Zob. G. Agamben, Stan wyjątkowy, tłum. M. Surma-Gawłowska, Kraków 2008. 
nierozstrzygalnością. Philippe Mesnard podsumowuje ten mankament następująco: „Binarna natura jego myśli czyni ją niebezpiecznie odwracalną, jako że może prowadzić do zamiany ról opozycyjnych par..."19.

Dlatego wprowadzenie przez Bielik-Robson "realnego dualizmu” w celu „zdynamizowania świata immanencji” podbija stawkę gry, czyniąc ją bardziej ryzykowną, ale i bardziej obiecującą. Posunięcie to wpisuje się w szerszy spór o gnostycyzm ${ }^{20}$, który przekłada się z kolei na spór o charakterze antropologicznym (pod postacią "metapsychologii”, czyli teorii psychoanalitycznej, jak za Freudem określa to sama autorka) oraz - w dalszej konsekwencji - dyskusję nad „uprawomocnieniem nowożytności". Zajmę się wyłącznie wymiarem antropologicznym, nawiązując do nieortodoksyjnych, głównie kabalistycznych, wyobrażeń o Stworzeniu, co pozwoli zrekonstruować wyłaniającą się z pism Bielik-Robson wizję człowieka jako problematycznego bytu energetycznego.

Jeśli dziś z trudem przychodzi nam pamiętać o tym, że w raju oprócz Drzewa Wiadomości Dobrego i Złego rosło także Drzewo Życia, i że ostatnim obrazem Nowego Jeruzalem z Apokalipsy jest przedstawienie Drzewa Życia jako życiodajnego źródła, to stało się tak w dużej mierze za sprawą Augustyna. W trzynastym rozdziale Państwa Bożego Drzewo Wiadomości symbolizuje wolę ludzką i przysługują mu wyłącznie negatywne konotacje, zaś Drzewo Życia oznacza mądrość, czyli posłuszeństwo Bogu. Augustyn nie przyjmował do wiadomości, że zerwanie owocu było czymś innym niż upadkiem i degradacją. Wiedzę uzyskaną po tym wydarzeniu zrównał on ze świadomością grzechu i wynikającym stąd wstydem ${ }^{21}$. Tymczasem alternatywne interpretacje traktują to radykalne zerwanie w kategoriach przejścia od kondycji zwierzęcej do ludzkiej, zyskania dostępu do „życia powiększonego” - oczywiście za cenę

19 P. Mesnard, The political philosophy of Giorgio Agamben: A critical evaluation, „Totalitarian Movements and Political Religions", R. V, 2004, nr 1, s. 143.

20 Y. Hotam, Gnosis and modernity - a postwar German intellectual debate on secularisation, religion and 'overcoming' the past, „Totalitarian Movements and Political Religions”, R. VIII, 2004, nr 3-4.

21 A. Benthall, A tale of two trees: Knowledge and life in the Book of Genesis, „Nova et Vetera" (English Edition), R. IX, 2011, nr 2. 
pewnych strat - co odpowiadałoby przywoływanemu przez Agatę Bielik-Robson za Erikiem L. Santnerem „wzmocnieniu przez redukcję ${ }^{\text {"22 }}$ (a co historycznie można łączyć z kryzysem nominalistycznym).

Ewa i Adam mieli uzyskać moc z Drzewa Życia dopiero po zerwaniu zakazanego owocu ${ }^{23}$. Przymierze byłoby w tej perspektywie wsparciem dla istoty słabej - słabej właśnie dlatego, że obdarzonej mocą, z którą mogłaby sobie nie poradzić. Bielik-Robson, posługując się idiomem psychoanalitycznym, mówi o tej problematycznej sytuacji następująco: „[...] byt obdarzony czystą energią popędową jest w istocie niezdolny do życia"24.

Ważne dla tej argumentacji jest odmienne od Augustyńskiego rozumienie mądrości. Podczas gdy Augustyn sytuuje ją w obrębie Drzewa Życia i identyfikuje z posłuszeństwem nakazom, kabaliści łączyli mądrość z Drzewem Wiadomości, inaczej ją na dodatek rozumiejąc. Dla Drzewa Życia rezerwowali jeszcze większe zadania. Wiedza o dobru i złu, zgodnie ze znaczeniem z późniejszych ksiąg Starego Testamentu, to mądrość, która sprowadza się do wyczucia, umiejętności trafnego sądu, nie tylko w dziedzinie moralnej, lecz także estetycznej, jest więc pojęciem z zakresu sztuki życia ${ }^{25}$. Po drugie, śmiertelność nie odróżniała rzeczywistości exodusu od egzystencji rajskiej, bowiem pierwsi rodzice, niczym zwierzęta, mieli nie zaznawać śmierci jedynie w sensie wiedzy o niej (jako że w myśli hebrajskiej wyłącznie Bogu przysługuje nieśmiertelność). Poza tym zasadnicza różnica w stosunku do zwierząt

22 A. Bielik-Robson, Rozbita konstelacja..., dz. cyt., s. 169.

23 Tak myślał m.in. św. Efrem z Syrii. Bliscy jego stanowisku komentatorzy podkreślali, że zerwanie owoców z Drzewa Wiadomości tak czy owak było przyobiecane ludziom, jednak pierwsi rodzice zbytnio pośpieszyli się, rozczarowując Boga, który chciał ich wystawić na próbę. W siedemnastym rozdziale Księgi Syracha znajduje się kilka fragmentów potwierdzających to, że wiedza z Drzewa Wiadomości nie była zła sama w sobie - wręcz przeciwnie. Sugeruje się tam także, że Bóg przeznaczył był ludziom współrządzenie. $Z$ tej obietnicy Stwórca wywiązał się niezależnie od biegu wypadków, oddając ziemię we władanie potomkom Ewy i Adama. Skóry, w które zostają odziani przed wyjściem z raju, są oznaką królewskiego splendoru, a nie - jak chciałaby tradycja postaugustyńska - znamieniem upadku. Zob. W. N. Wilder, Illumination and investiture the royal significance of the tree of wisdom in genesis 3, „Westminster Theological Journal”, R. LXVIII, 2006, nr 1. Zob. także J. Fritzpatrick, Original sin or original sinfulness?, „New Blackfriars”, R. XC, 2009, nr 1030, s. 66-72.

24 A. Bielik-Robson, Romantyzm..., dz. cyt., s. 35-36.

25 W. N. Wilder, Illumination..., dz. cyt., s. 54. 
tkwi w fakcie utraty bezpiecznej niszy środowiskowej na rzecz poszerzenia zakresu możliwości powstałego wyłącznie dzięki zdolności dystansowania się od natury. Narracja ta przypominałaby w dużej mierze tę, jaką w pierwszym rozdziale Arbeit am Mythos przedstawił Hans Blumenberg, w stosunku do której jednak Agata Bielik-Robson dokonuje „drobnej poprawki”26.

Opis Blumenberga dotyczy hipotetycznej sytuacji pierwotnej odpowiadającej powstaniu ludzkiego zwierzęcia, które po opuszczeniu bezpiecznego otoczenia musiało zmierzyć się z tzw. „absolutyzmem rzeczywistości", całkowicie obcym i zagrażającym życiü ${ }^{27}$. Fundamentalny jest w tej koncepcji lęk, stąd wszystkie późniejsze, wymagające sprytu i przemyślności uniki, jakie człowiek czyni, by odsunąć groźbę unicestwienia, podpadają pod kategorię kompensacji. Pomimo licznych zalet Blumenbergowskiej opowieści, o których nie będę tu szerzej mówić, ma ona tę wadę, że życie widziane jest w niej zawsze przez pryzmat śmierci, co odpowiada strategii tragicznej (mimo że wymyka się jej z uwagi na zredukowaną rolę winy).

Natomiast Bielik-Robson sięga po motyw Drzewa Życia, by - podobnie jak większość kabalistów - dostrzec w nim symbol przyobiecanej pełni - anarchicznej, bezmiernej „rozkoszy i radości”28. Pierwszeństwo Drzewa Życia oznacza rewolucję w ujmowaniu gnostycyzmu, którą trafnie oddają słowa Jacoba Taubesa: „Bóg ukryty (absconditum) promuje nie grozę, lecz autentyczną radość" ${ }^{29}$. Śmierć i cierpienie nie zostają tym samym unieważnione, lecz w pewnej mierze odsunięte ${ }^{30}$, stwarzając nieco wolnej przestrzeni, „luzu” jako miejsca do życia powiększonego, a nie jakiegokolwiek. Posługując się inną metaforą, można

26 Terminem „drobna poprawka” (ein geringes Zurechtstellen) posługuje się Bielik-Robson, zapożyczając go od Benjamina. Oznacza on nieznaczną, lecz w gruncie rzeczy zasadniczą, zmianę. Warszawa 2009.

H. Blumenberg, Praca nad mitem, tłum. oprac. K. Najdek, M. Herer, Z. Zwoliński,

28 A. Bielik-Robson, Erros. Mesjański witalizm i filozofia, Kraków 2012, s. 40.

29 J. Taubes, From cult to culture. Fragments towards a critique of historical reason, red. A. Assmann, Stanford 2009, s. 145, cyt. za: A. Bielik-Robson, Erros..., dz. cyt., s. 40.

30 Cierpienia nie da się uniknąć, ale jest wtórne wobec pierwotnej radości. Zob. tamże. 
mówić o głębszym oddechu. A metafora ta przywodzi na myśl kabalistyczną koncepcję cimcum, będącej przemyślnym uzupełnieniem biblijnego opisu Stworzenia. Wedle tego wyobrażenia boska pełnia postanowiła, jak opisuje to Hans Jonas, „powierzyć siebie przypadkowi”, „wejść w przygodę czasu i przestrzeni” ${ }^{31}$, dokonując samoograniczenia, redukcji do nicości. Aby zaistnieć mogło cokolwiek, trzeba było radykalnej separacji. Zdaniem Jonasa życie było pierwszą zasadą ${ }^{32}$. Pojawieniu się człowieka odpowiada „[...] powolne wynurzanie się transcendencji z nieprzejrzystej immanencji”" ${ }^{33}$. Taubes niejako dopowiada dalszy ciąg tej narracji, wskazując na apostazję jako zbawienne źródło wolności, co w cytowanym przez Bielik-Robson fragmencie Zachodniej eschatologii brzmi: „Tylko odpowiedź ludzkości na słowo Boga, mające charakter negacji (ein Nein), świadczy o ludzkiej wolności. Wolność negacji - oto właściwy początek historii”34.

Koncepcja cimcum zawiera kilka znaczących sugestii etycznych. Mianowicie: etyka ma coś wspólnego z siłą i zajmowaniem miejsca. Tylko podmiot silny (czyli odseparowany) może w sposób nieresentymentalny dokonać samoograniczenia. Bielik-Robson mówi w tym wypadku o pierwszeństwie wszelkiej pojedynczości przed całością, bowiem dopiero z tej pozycji można zacząć dyskutować o ustępstwach. Po drugie, śmierć nie jest skutkiem winy, lecz ceną, jaką płaci się za życie niepoddane w całości biologicznemu determinizmowi.

Spróbuję zasugerować możliwość translacji tych idei na spekulację natury psychoanalitycznej i przedstawić witalizm mesjański jako strategię wspierającą udany proces indywiduacji. Agata Bielik-Robson lubi przytaczać słowa Williama Blake’a: „Energia jest radością”. Psychoanalityczne dociekania dotyczące życia płodowego idą, jak się zdaje, w tym kierunku. Okazuje się bowiem, że okres prenatalny potrafi zasadniczo wpłynąć na

31 H. Jonas, Idea Boga po Auschwitz, tłum. G. Sowinski, Kraków 2003, s. 34.

32 Co odpowiada tezie Jonathana Leara o nieistnieniu popędu śmierci. Zob. A. Bielik-Robson, Erros..., dz. cyt., s. 19.

33 H. Jonas, Idea Boga..., dz. cyt., s. 35.

34 J. Taubes, Occidental eschatology, tłum. D. Ratmoko, Stanford 2009, s. 5, cyt. za: A. Bielik-Robson, Erros..., dz. cyt., s. 33-34. 
dynamikę całej egzystencji. Długotrwałe poczucie zagrożenia, spowodowane dopływem szkodliwych substancji lub negatywnych sygnałów płynących od matki lub otoczenia, może wywołać trudne lub niemożliwe do odrobienia straty uwidaczniające się w procesie formowania ego.

Komentując pewien fragment $\mathrm{z}$ Benjamina, Bielik-Robson mówi o „niewykorzystanych i sparaliżowanych energiach"35, co odpowiada procesowi zakłóconej indywiduacji, kiedy dochodzi do zaburzenia dialektyki siły i słabości, która zamiast wspierać emancypację prowadzi do regresu blokującego osiągnięcie dojrzałości. Krótko mówiąc, chodzi o denaturalizację bez popadania w sztuczne i toksyczne zależności, a także bez konieczności przyjmowania strategii tanatycznej ${ }^{36}$. W tym miejscu mała uwaga: nie mając pewności, co dokładnie ma na myśli Bielik-Robson, kiedy twierdzi, że dla witalizmu mesjańskiego nie ma rzeczy niezbawialnych ${ }^{37}$, jestem skłonny mimo wszystko upierać się przy tym, iż nieusuwalny tragizm występuje właśnie $\mathrm{w}$ związku z niepowetowanymi stratami sprzed indywiduacji, a także $\mathrm{w}$ obszarze winy indywidualnej, która nie spotkała się z przebaczeniem.

W porównaniu z dialektyczną złożonością zarysowanego wyżej antropologicznego wymiaru witalizmu mesjańskiego refleksja Agambena wydaje się niewystarczająca jako podbudowa dla projektu emancypacyjnego, czy to w wymiarze indywidualnym, czy zbiorowym. Lęk przed byciem, w mocnym sensie tego słowa, skutkuje koncepcją podmiotu „zanikającego", która zaczyna przypominać w najlepszym razie Melville'owskiego Bartleby'ego powtarzającego swoje słynne „I would prefer not to", a w najgorszym kumuluje w postaci obozowego muzułmana pozbawionego zdolności mówienia i działania. I o ile Bartlebiańska formuła mogłaby zostać uznana za zbawienną jako - mówiąc za Blumenbergiem - apotropaion odsuwający nieszczęście, czyli jako zaledwie pierwszy krok na drodze do samoutwierdzenia (Selbstbehauptung), o tyle

35 A. Bielik-Robson, Romantyzm..., dz. cyt., s. 18.

${ }_{36}$ Bielik-Robson podkreśla, że antynaturalizm właściwy witalizmowi mesjańskiemu to nie walka z biologią ( $\mathrm{z}$ faktycznością), lecz z renaturalizacją, z naiwnymi i niemożliwymi w gruncie rzeczy próbami „powrotu do natury”. Zob. taż, Erros..., dz. cyt., s. 16, 32.

37 Taż, Rozbita konstelacja..., dz. cyt., s. 181. 
jest nie do przyjęcia, jeśli miałaby być gestem ostatecznym, bowiem równa się wtedy melancholijnej repetycji - jałowemu kręceniu się w kółko bez nadziei na jakiekolwiek wyjście (nie mówiąc już o Wyjściu).

Kiedy Agamben sięga po figurę dziecka, czyni to po to, by wykorzystać ją do egzemplifikacji gestu profanacyjnego, w którym upatruje możliwość przekroczenia współczesnego paradygmatu polityczności. Profanacja występuje przeciw wszelkiej separacji: „Poświęcać (sacrare) oznaczało przenieść rzeczy poza sferę prawa ludzkiego; profanowanie było zatem restytucją, ponownym przekazaniem ich ludziom do swobodnego użytku"38. Przykładem takiego działania staje się dziecięca zabawa z jej niefrasobliwością. Dzieci bowiem nie respektują wartości obowiązujących w świecie dorosłych i dlatego zdolne są do niszczenia np. ważnych dokumentów, pieniędzy. Agamben zdaje się nie dostrzegać istotnego elementu takiej zabawy, mianowicie stojącej za destrukcją przemocy.

Właśnie owa wielce niepedagogiczna nieumiejętność poradzenia sobie z mocą, czyli nieprzewidywalnością, nieuchronnie skłania włoskiego filozofa do unieszkodliwiania podmiotu kosztem jego twórczych potencji. Obawa przed przysługującą żywotnemu bytowi ludzkiemu nadmiarową energią skrywa manichejską pokusę wycofania się z istnienia, poszukiwania jakiejś niemożliwej ontologii. Mówiąc językiem polityczności: Agamben nie jest w stanie poprzeć żadnego projektu, bowiem potępił wszystkie charakterystyczne dla modernitas kategorie, nie dysponując innymi. Zamiast wspierać ludzką istotę, jak czyni to Blumenberg czy Bielik-Robson, wybiera regresywną postawę lękową i nie potrafi docenić zasady racji dostatecznej, dostrzegając w niej wyłącznie arbitralnośćc ${ }^{39}$.

W Profanacjach pojawia się niezwykle interesująca teza: przeciwieństwem religii nie jest sceptycyzm, lecz niedbalstwo, lekkomyślna

38 G. Agamben, Profanacje, tłum. M. Kwaterko, Warszawa 2006, s. 93.

39 A. G. Hervás, La gloria y el concepto de lo político en Giorgio Agamben, „Revista de Estudios Sociales”, 2010, nr 35, s. 75. W podobnym duchu pisała Bielik-Robson, zarzucając liberalizmowi, a jeszcze bardziej myśli lewicowej, „przedelikacenie”. Zob. A. Bielik-Robson, Romantyzm..., dz. cyt., s. 323. 
nieuważność i beztroska ${ }^{40}$. Tymczasem Bielik-Robson obiera odmienną drogę, akcentując moment sceptycznej uważności i powstrzymania się jako fundamentalny dla wszelkiej etyki ${ }^{41}$. Jednocześnie postuluje horyzontalną wizję wspólnoty, nie wykluczając Prawa, lecz proponując poszukiwanie nowego Prawa ${ }^{42}$, uwewnętrznionego - „o ile to tylko możliwe"43 - ale takiego, które przemieni się w miłość bliźniego, nawiązanie relacji z nim poza metafizyką ${ }^{44}$.

Kluczowa jest tu zaczerpnięta z Franza Rosenzweiga i tradycji mistycznej postać bliźniego, występującego jako Platzhalter - ktoś, kto zajmuje określone miejsce ${ }^{45}$. Uważam, że źródła tego przekonania tkwią w afirmacji faktu ludzkich narodzin. Jego doniosłość podkreślała Arendt, upatrując w nim ontologicznego ugruntowania dla prawdziwie ludzkiej zdolności zaczynania na nowo, mówienia i działania. Narodziny to cud, czyli zjawienie się czegoś nieoczekiwanego, Augustyńskie initium. Dziecko zaś to nadzieja na trwałość świata - pomimo kruchości spraw ludzkich $^{46}$.

Rozumiejąc, że człowieka nie sposób stale utrzymywać w sferze czystej potencjalności, Arendt opowiadała się za chwałą obecną w dziełach, czynach i słowach, a zarazem broniła otwartości na to, co nowe

40 G. Agamben, Profanacje..., dz. cyt., s. 94-95. Na marginesie warto dodać, że właśnie te określenia stanowią treść greckiego odpowiednika acedii - największej skazy przypisywanej w dawnych wiekach melancholikom, przez którą tracili oni wszelką nadzieję, łącznie z ufnością względem łaski udzielanej przez Boga. Zob. M. Bieńczyk, Melancholia..., dz. cyt., s. 96n.

$41 \quad$ A. Bielik-Robson, Romantyzm..., dz. cyt., s. 133.

42 Tamże, s. 134.

43 Tamże, s. 327-328.

44 Taż, Rozbita konstelacja..., dz. cyt., s. 178, 182. Żeby nie doprowadzić do zrównania myśli Bielik-Robson z filozofią dialogu, wspomnę, że w tekście „Cogito”, albo narodziny nowoczesności z ducha gnostyckiego paradoksu. Hansa Blumenberga lektura Kartezjusza autorka w ślad za Blumenbergiem dowartościowuje nowoczesny gest autoasercji (Selbstbehauptung), który pozwala sytuować relacje podmiotowości między dialogiem a solipsyzmem. Zob. Deus otiosus. Nowoczesność w perspektywie postsekularnej, red. A. Bielik-Robson, M. A. Sosnowski, Warszawa 2013, s. $39-89$.

45 A. Bielik-Robson, Romantyzm..., dz. cyt., s. 177-178.

46 Zob. H. Arendt, Kondycja ludzka, tłum. A. Łagodzka, Warszawa 2000, s. 195-196, 267-268 oraz esej Kryzys edukacji: taż, Między czasem minionym a przyszłym: osiem ćwiczeń z myśli politycznej, tłum. M. Godyń i W. Madej, Warszawa 1994. 
i nieprzewidywalne, nie zapominając przy tym o uzasadnionych i pożądanych sposobach radzenia sobie w tej złożonej sytuacji: w stosunku do nieodwołalności czasu minionego pozostaje możliwość przebaczenia, a w stosunku do przyszłości - zdolność składania obietnic.

Odnosząc się do eseju Benjamina poświęconego Powinowactwom $z$ wyboru, Bielik-Robson pisze o „[...] nadziei pozbawionej nadziei jako oczekiwaniu, które możemy żywić tylko ze względu na innych, nigdy nas samych" ${ }^{47}$. Słowa te padają w kontekście niwelowania winy. Otóż o ile nominalizm powoduje zamianę uogólnionej winy tragicznej w moralną, to bez bliźniego, bez jego przebaczenia, nie sposób odsunąć właśnie tej drugiej - krzywdy uczynionej konkretnemu człowiekowi. Witalizm mesjański sięga zatem po żywotne, a rzadziej dziś przywoływane pojęcia woli i pamięci, będące bliżej życia niż nieskończone mnożenie niemożliwości, lękliwie cofające się w geście odmowy uczestnictwa.

Nadzieje wszelkiego witalizmu i każdej antropologii muszą w końcu zmierzyć się z figurą dziecka, która jest dla nich swoistym papierkiem lakmusowym. Ta figura umożliwia dociekliwe zapytywanie, czy dana myśl jest w stanie sprostać obietnicy emancypacji tkwiącej w koncepcji upodmiotowienia. By tak się stało, potrzeba przede wszystkim uważnego obchodzenia się z energetycznym potencjałem człowieka, któremu szkodzi zarówno pragnienie woli mocy, jak i absolutyzacja słabości. Wyrafinowana sztuka życia powinna bowiem sprzyjać nieprzewidywalności i nie studzić tlącego się w niej ognia, którego blask przypomina o tym, „[...] że ludzie, chociaż muszą umrzeć, nie rodzą się, by umrzeć, ale by rozpoczynać" 48 .

47 A. Bielik-Robson, Rozbita konstelacja..., dz. cyt., s. 181.

48 H. Arendt, Kondycja..., dz. cyt., s. 267. Na temat emancypacyjnego potencjału antropologii filozoficznej Arendt pisałem w innym miejscu. Zob. R. Zawisza, Ocalić to, co się da. Witalistyczna interpretacja rozprawy doktorskiej Hanny Arendt pt. „O pojęciu miłości u Augustyna”, „Praktyka Teoretyczna”, 2012, nr 6, s. 327-346, www.praktykateoretyczna.pl/PT_nr6_2012_Roza_ Luksemburg/18.Zawisza.pdf (11.02.2014). 


\section{Bibliografia}

1. Adorno T. W., Dialektyka negatywna, tłum. K. Krzemieniowa, Warszawa 1986.

2. Agamben G., Co zostaje z Auschwitz: archiwum i świadek, tłum. S. Królak, Warszawa 2008.

3. Agamben G., „Homo sacer”. Suwerenna władza i nagie życie, tłum. M. Salwa, Warszawa 2008.

4. Agamben G., Profanacje, tłum. M. Kwaterko, Warszawa 2006.

5. Agamben G., Wspólnota, która nadchodzi, tłum. S. Królak, Warszawa 2008.

6. Bałus W., „Mundus melancholicus”: melancholiczny świat w zwierciadle sztuki, Kraków 1996.

7. Bielik-Robson A., Erros. Mesjański witalizm i filozofia, Kraków 2012.

8. Bielik-Robson A., Romantyzm. Niedokończony projekt. Eseje, Kraków 2008.

9. Bieńczyk M., Melancholia. O tych, co nigdy nie odnajda straty, Warszawa 1998.

10. Hervás A. G., La gloria y el concepto de lo político en Giorgio Agamben, „Revista de Estudios Sociales”, 2010, nr 35.

11. Hotam Y., Gnosis and Modernity - a Postwar German Intellectual Debate on Secularisation, Religion and 'Overcoming' the Past, „Totalitarian Movements and Political Religions", R. VIII, 2004, nr 3-4.

12. Jonas H., Idea Boga po Auschwitz, tłum. G. Sowiński, Kraków 2003.

13. Kierkegaard S., O różnicy między geniuszem i apostołem, [w:] tenże, Pisma mniejsze, tłum. K. Toeplitz, Toruń 2007.

14. Klibansky R., Panofsky E., Saxl F., Saturn i melancholia. Studia z historii, filozofii, przyrody, medycyny, religii oraz sztuki, tłum. A. Kryczyńska, Kraków 2009.

15. Mesnard P., The Political Philosophy of Giorgio Agamben: A Critical Evaluation, „Totalitarian Movements and Political Religions”, R. V, 2004, nr 1. 